\title{
The smell of coffee, blood and disinfectant ...
}

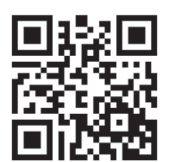

He's the guy who 'makes and loves the coffee' - which is probably just as well, because he's one of only two emergency medicine specialists on night duty at Khayelitsha Hospital, and will soon have to hyper-focus; it's pay-day weekend.

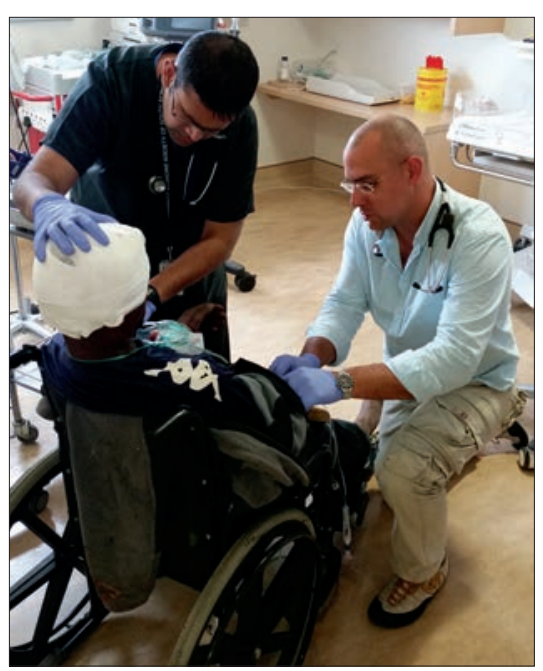

Dr Sa'ad Lahri and colleague Dr Hendrik Lategan.

The against-the-odds saving of lives that takes place is as unbelievable to less trauma-hardened medics, as is the sure-fire predictability of this month-end patient influx, says Dr Saad Lahri. Only the types of severe trauma differ as he, consultant colleague Dr Hendrik Lategan, four other doctors and 15 nurses make snap decisions that will save the lives of $80 \%$ of their patients, most of whom are inebriated. The million-plus-strong township thrums on a payday weekend as shackland taverns, open houses and street parties generate music, frivolity and profit, belying the chaos that inevitably ensues as disinhibited energies (read: pent-up frustrations) spill over into multiple episodes of uncontrolled violence. Small worked-up crowds ebb and flow between venues, and long-standing gang animosities often explode, sparked by seemingly minor incidents. At the same time, domestic disputes boil over behind brick, corrugated-iron or cardboard walls, incurring multiple casualties as neighbours also living on or below the breadline try to intervene or take sides. Lahri and his colleagues meanwhile savour what could at any second be their last cup of his much-loved special coffee blend as the admission rate begins to pick up ...

\section{Mending hearts in more ways than one}

'Most of our cases are penetrating traumatic injury to the chest - these criminals read the anatomy books, they know where to stab. His team's stab-heart survival rate is $75 \%$, an incredible $60 \%$ above the international survival norm listed in the medical literature. They've had 60 stabbed hearts at the emergency centre over the past 2 years, and have saved 45 of the patients. One case he'll never forget: the youth's left anterior descending coronary artery was severed. 'We managed to stabilise and get him into theatre. The surgeon used a feeding tube to create an artificial artery, and we were then able to get him to Groote Schuur for a bypass.' The second highest trauma category is traumatic brain injury from community assaults, 'and then we get the car accident patients, mostly off the [nearby N2]', Lahri says, pausing to field the barrage of questions that countless interviews have taught him will ensue. Yes, 90\% of the trauma cases are alcohol-related, but the thing that has stood out during his 2-year tenure is the timing of this human tidal wave of patients: 'It's very clear; it's the first or second day of every month; whenever there's money and alcohol.' What 'bugs' him most, though, are the three to four new patients with drug-induced psychosis admitted every day (about 110 per month), most of whom have committed active crimes. Very few have schizophrenia or other psychiatric conditions. Police baulk at arresting these people because they are 'deurmekaar' (confused) and need to brought down first meaning that the emergency unit staff faces the brunt of their destructive behaviour. Says Lahri: 'They break windows, equipment, assault staff. We had one guy fall through the ceiling after he somehow got into the roof through a trapdoor. It's a major issue. They also sell their parents' stuff. One mum came in crying, saying he'd sold everything in the house, fridge, stove and chandeliers - the lot. We just treat symptomatically and wait for the psychiatric professionals to come. They sometimes lie with 


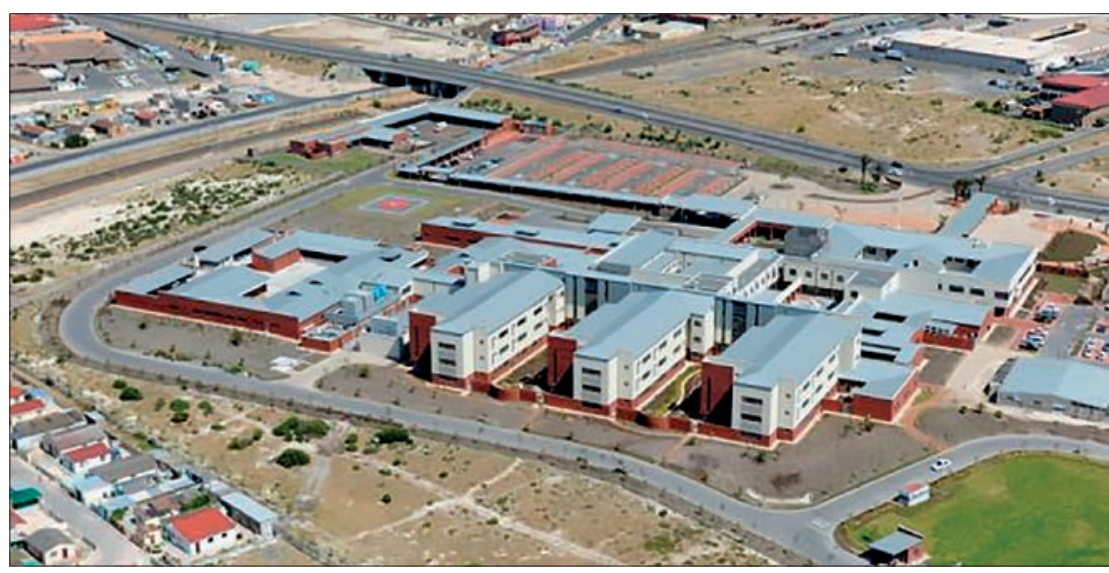

An aerial view of Khayelitsha's new hospital.

us for days. We try to interact with FAMSA and SANCA and the community health centres (who have psychiatric nurse practitioners), but our job is to deal with the critically ill. Drug abuse gets in the way of everything else'. Asked to quantify the problem, he responds: 'It's about $3 \%$ of my load but $70 \%$ of my problem.'

\section{Vigilante violence puts police in the shade}

The other disturbing phenomenon for Lahri is the community assaults. 'We have people being beaten for stealing chickens. The community gets hold of them and beats them to a pulp, mostly resulting in severe traumatic brain injury, or just simply burns them alive via the necklace method' (a legacy of the civil warfare that raged in townships during the apartheid years, when suspected 'impimpis' (sell-outs) were beaten, and a petrol-filled car tyre slung around their necks and set alight). Asked to quantify the mob attacks, he puts the figure at around ten victims per weekend and 'at least 30 ' per month.

Lahri counts himself lucky staffing-wise (he only has to compare his situation with similar hospitals anywhere in the country), but cannot escape the dearth of appropriately trained nurses. Many of his are agency or locum nurses, which he, like many of his frustrated colleagues nationally, considers unsustainable when it comes to quality control. Six are traumatrained, a result of smart forward thinking when he and Lategan sent two a year on trauma and resuscitation courses, leading to short-term work pressure but substantive long-term relief. Given a magic wand, hed conjure up a third consultant, giving himself and his colleague more time to handle admin and write up some of their more noteworthy resuscitations and treatment (he's managed to get just four papers published in over 2 years). Both he and Lategan are family men with young children. 'We're the only two, so we have to have one another's backs; it gets rough sometimes - it's not just the volumes, the patients are complicated, we have polytrauma, airway injuries, patients with gunshot-face and stabbed neck, it's not simple stuff. Then there are the medical admissions, also driven by poor housing, lack of potable water and sanitation, and other povertyrelated factors. 'We see a lot of the massive HIV/tuberculosis (TB) burden via presenting emergencies. They will arrive in septic shock, with cardiac tamponade from $\mathrm{TB}$ or have massive diarrhoea with a potassium count of $0.5 \mathrm{mmol} / \mathrm{l}$. The unit sees about 700 children a month on average, rising to 1200 per month in the December - April 'surge season' when diarrhoea and pneumonia are most prevalent. Overall, paediatric mortality in the township has opened its doors in on 17 April 2012 (all traumarelated deaths have plummeted by $80 \%$ ). Lahri's team deals with an unusual amount of pulmonary embolisms and has thrombolised 'at least 20 ' patients over the past 2 years (compared with, say, Victoria Hospital or the ultra-modern and also relatively new Mitchell's Plain Hospital, myocardial infarction).

\section{Most memorable cases}

Besides one horrific night when a crazed knifeman slit the throats of several local residents, Lahri's most memorable cases include a child who was playing with an electric live wire and was electrocuted. A member of the community ran in with him and we immediately defibrillated the child. We intubated, ventilated and got him to Tygerberg - he survived', he says with barely disguised pride. The 'night of the knifeman' included a patient whose neck had been 'slit open like a sheep at the Adam's apple. Emblazoned in the memories of all who helped save him are his gurgling screams and the blood spray-painted across themselves, the room and the walls. Overseas doctors who 'parachute in' for the unparalleled work experience are generally the most 'freaked dropped by more than $50 \%$ since the hospital where thrombolysis is normally associated with out', Lahri says (there's a waiting list of foreignqualified doctors stretching to 2016).

Asked about the prevalence of posttraumatic stress disorder among his colleagues, Lahri responds: 'We actively manage all the situations. Whenever stuff happens, we actively debrief. We go through about $5 \mathrm{~kg}$ of coffee a week! We begin by asking them what they think they did well, what could have been done better, and then ask if there's anything troubling them about the case. It always comes down to "Hey! You didn't shoot the guy, you did your best!"' The unit's caseload stands at about 3000 patients a month and has remained relatively static, peaking at over 100 patients per day on month-end weekends.

Asked about travelling to and from the hospital and security at the hospital itself, Lahri says he has 'no issues.' 'To come in and travel out has been fine, and our hospital security is awesome. They tend to block a lot of the nonsense, with guns and knives usually handled by the ambulance staff or our security searching patients. We've had patients coming in with weapons, but it's sorted out very quickly.' Contrary to a widely held negative perception following reportage of an official probe into the township's police force, he has nothing but gratitude for Khayelitsha's policemen and women. 'Every time we've called, they're here within $10-15$ minutes. Take an alleged rapist the community beat up: the cops come in, take a statement and then guard him. We had one cop here the other day who stepped into the middle of a mob that was busy savaging one guy and saved him, promising on his life that the suspect would go back to jail from the courts and giving the crowd his personal cell phone number. $\mathrm{He}$ stayed here well past his shift - until the guy was discharged - and then took him back to a holding cell:

Lahri, a former consultant at the notoriously busy GF Jooste Hospital Emergency Unit in the heart of the Cape Flats ganglands, shut down in a rationalisation/modernisation initiative early last year, knows that the latter only partially contributes to his hospital's $131 \%$ overall bed occupation level. The other major factor is Khayelitsha's highly migrant population, whose healthcare in the Eastern Cape cannot match that available locally. About $70 \%$ of the adults living in the township come from the Eastern Cape, while most people under 19 were born locally. 'We have a major influx from the Eastern Cape, often chronic patients, especially cancer, many in the last stages.' He gave one heroic example of a child with a fractured femur, brought in via longdistance taxi from Umtata by his barely older sister, who had extracted him from a hospital where he had lain unattended for 'weeks'. 


\section{International study dovetails with trauma profile}

Khayelitsha and Rio de Janeiro were recently the subjects of a 32-month international comparative study by the Human Sciences Research Council, (HSRC) on the role of social cohesion (or social solidarity) in understanding the link between inequality, poverty and urban violence. ${ }^{[1]}$ The report cited Khayelitsha's murder rate as between 76 and 108/100 000 at the township's various police stations (the South African average being 31), and said there were 'high levels of fear of violence in all social spheres, including many public spaces'. Evidence at the recent Commission of Inquiry into policing in Khayelitsha indicated that the police perceived the township as an impenetrable space that they could not police. As a result, they failed to intervene and appeared to police 'at the margins' of the community. The HSRC report said that youth gangs were 'a significant form of social organisation'. Although not organised in the same way as the gangs on the Cape Flats, they were shaping the nature and meaning of public space in places such as parks and schools. They were 'highly territorial and shape identity, as young boys in particular areas feel obligated to join their local gang' These gangs had a particular language of violence, which was very much about a public display of power. The report said that the collective violence residents engaged in was also organised as a public spectacle, intended to enforce a moral community against an 'other'. This 'other' shifted, and might be a foreigner, a criminal or some other category of person.

\section{Embrace your heroic work - and stop whining}

Lahri's 47-bed accident and emergency unit is $30 \%$ larger than a standard district hospital trauma unit, and the hospital has a heliport and a fleet of 11 ambulances and 110 paramedics and drivers.
Asked what his core message was for his emergency medicine colleagues $(70 \%$ of them female), who work 9-hour days and every second weekend, Lahri replied: 'I tell the younger ones there are very few chances in life to be a hero(ine) - and sometimes being a doctor here is just that. I define a hero as someone who finds the strength to persevere in spite of the obstacles - that's certainly my motto. Things will always be difficult - it's about persisting. When you see that mother hug her child, it's all worth it. I sometimes tell my guys on night shift, when they're really tired and irritated: "Just remember someone else still has a family member because of you ... so stop whining!"”

\section{Chris Bateman}

chrisb@hmpg.co.za

S Afr Med J 2014;104(11):727-729. DOI:10.7196/SAMJ.9004

1. Barolsky V. Violence in Khayelitsha: Finding a way out. HSRC Review 2014;12(4):8-11 